\title{
Ssciendo
}

Journal of KONBiN 2020

Volume 50, Issue 4

DOI 10.2478/jok-2020-0071

\author{
Andrzej HANUSIK
}

University of Economics in Katowice (Uniwersytet Ekonomiczny w Katowicach)

\section{RISK IN CARSHARING - IDENTIFICATION AND ASSESSMENT}

\section{Ryzyko w carsharingu - identyfikacja i ocena}

\begin{abstract}
The purpose of this article is identification of risks in carsharing and their latter assessment in terms of probability of occurrence, impact on customer relationships, importance of a given category and cost they generate. A way of aggregating various categories of risks into one synthetic indicator in order to prioritize them was proposed. Methodology of the process was based on a methodological triangulation which is based on the following studies - analysis and criticism of literature which helps to place discussed research problem on theoretical basis, qualitative research and observations allowing to identify individual categories of risks and quantitative research enabling the description of given categories of risks by appropriate variables on which further risk modelling is performed. Such research may be a basis to subsequent analysis and be an impulse to an academic debate. Also it may contribute to creation of further studies dealing with the problem of assessment of the risk in concepts related to sharing economy.
\end{abstract}

Keywords: sharing economy, carsharing, risk assessment

Streszczenie: Celem niniejszego artykułu jest identyfikacja ryzyk występujacych $w$ działalności carsharingowej oraz ich późniejsza ocena pod względem prawdopodobieństwa wystapienia, wpływu na relację z klientem, istotności danej kategorii oraz kosztów, jakie generuja. Zaproponowany został również sposób agregacji różnych kategorii ryzyk do jednego wskaźnika syntetycznego, w celu dokonania ich hierarchizacji. Metodyka procesu oparta została na triangulacji metodologicznej, która zwiazana jest z trzema kategoriami badań - analiza i krytyka piśmiennictwa, pozwalajaca na umiejscowienie omawianego problemu badawczego w podstawach teoretycznych, badania jakościowe i obserwacje umożliwiajace identyfikacje poszczególnych kategorii ryzyk oraz badania ilościowe, które pozwalaja opisać poszczególne kategorie ryzyk poprzez wykorzystanie odpowiednich zmiennych stużacych do modelowania ryzyka. Tak przeprowadzone badania stanowić moga fundament do dalszych analiz oraz być impulsem do debaty akademickiej na temat oceny ryzyka w koncepcjach zwiąanych z ekonomia współdzielenia.

Słowa kluczowe: ekonomia współdzielenia, carsharing, ocena ryzyka 


\section{Introduction}

The modern market is a very dynamic composition, which forces the search for newer and more innovative solutions. Certainly, it can be assumed that the kind of advantage of the modern world is the creativity of business entities and consumers, and thus also innovation which is present on the free market (reflected by actions of enterprises or marketbased organizations) [1] on the non-market social level (especially individual but group as well) and even in the sector of government entities [15]. A globalization and extremely rapid development of technologies can be considered as factors of these changes. Also, they are pushing the world towards an increasingly homogenous community. These changes concern not only the way of communication, increasing mobility or standardization of offered products but also the way of thinking (economic, social and cultural). This situation causes the emergence on market of new concepts of offering and using services or items.

Increasingly, both in the business models of enterprises and in the consumption behaviour of people, it can notice the phenomenon of shifting the focus in the approach to economic goods. Business entities seem to be more aware of the fact that more economically effective is an access to a given good than the necessity of possessing it. Sharing economy is a process involving the joint use of goods by many entities, extended by the aspect of engaging in joint activities [5]. Therefore, the approach to ownership and market exchange is under transformation [16]. Hence, the entity receives only a certain unit of time specified in contract, in which it can use the given food - acquires the right to temporarily use it [12]. That situation allows to increase the productivity of the economy and contributes to minimize the phenomenon of exclusion. The weakness of that concept is the potential anonymity of entities using shared good an the possibility of improper use of the good - there is a risk, that the entity, which only uses given good, may not care for it as much as in the situation that it owns it. It may results in decreasing the quality of commonly used goods.

Carsharing is one of the elements of the sharing economy. Carsharing consist in paid access to a car, which is not fully used by its owners (in case of private carsharing) or to a specially adapted vehicle for a short rental (in case of business carsharing). An access to a vehicles is based on one-time or periodic payments. Cars are used almost only used to short, local tourneys, because costs become too high when renting a car for a longer period of time [2]. The whole transaction is concluded and settled through the use of dedicated application - so there is no need for direct contact with a client. The use of sharing economy (including carsharing) in urban areas may contribute to the improvement of the transport situation in a given area - transport will become cleaner, more intelligent and more sustainable. Also mobility behavior of citizens and business entities will change, which will contribute to increasing the efficiency usage of infrastructure and reduction of cost [6]. Such a solution is a very convenient form for the consumer, however, it is associated with an increased risk for the entity offering carsharing services.

It can be presumed that concepts related to sharing economy will develop dynamically in the future. It is related to the market itself and the nature of Y-generation, which is more 
and more active on the market. That generation is definitely more willing to search for innovative solutions, thus they gladly use sharing economy. On the other hand, Y-generation is eager to take risky actions [7], which has an impact on the costs and risk bore by carsharing operators. Therefore, it is necessary to identify risky activities and probability of their occurrence, which will allow entities offering carsharing services to create an efficient and effective risk management system.

\section{Methodology and data}

The research methods and techniques used in the work were based on methodological triangulation (fig. 1). This structure of the study allowed for an in-depth analysis of the problem and for obtaining more reliable conclusions.

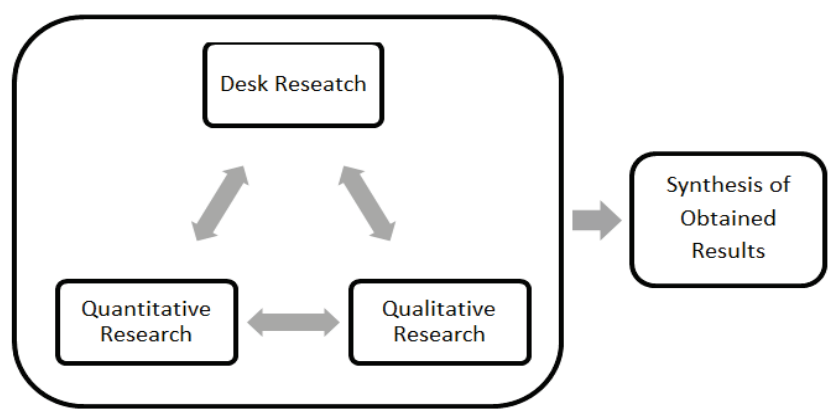

Fig. 1. Methodological triangulation used in the article

In the first part of the article the method of analysis and criticism of literature (desk research) were used. It includes a systematic and orderly study of previous scientific endeavours and the existing publication resources [4]. The use of this method allowed the identification of the research problem and to define ways to solve it.

To identify risks that occur in carsharing activities the observations were made. This method consisted of discreet observation of people using carsharing, their behaviour when renting a vehicle, its use and return. This allowed to identify types of risks that should be taken into account in the risk analysis.

Next, the IDI (Individual In-depth Interview) method was used. In-depth interview is a qualitative research technique. It involves conducting intensive individual interviews with a small number of respondents. The result of interviews is information about their knowledge and point of view on the selected topic. IDIs are used in the case of new research problems that were not previously scientifically discussed or were discussed to a small extent [3]. In-depth interviews have been conducted with carsharing users, sharing economy 
experts, and carsharing services providers. The structure of the interviews was semi-structured (respondents were asked questions in accordance with the prepared scenario, however, freedom of expression was allowed). Conducted interviews allowed the identification of subsequent risk categories and their initial assessment.

The last step related to collecting data was conducting an survey about the assessment of individual risk categories in terms of likelihood of their occurrence, impact on customer relations (if detected by the customer) and a subjective indication of a maximum of 3 risks most relevant to car sharing activities. 528 people took part in the survey (snowball sampling). The survey was conducted from October 1, 2019 to October 22, 2019, using the paper and online form. 14 surveys were rejected due to wrong filling, lack of information or illegibility.

Next, on the basis of previous steps and additional analyses, individual risk categories were assessed in terms of the following indicators:

- $\mathrm{X}_{1}$ - probability of risk occurrence (expressed in the form of assessments obtained through surveys), where:

$$
\begin{array}{ll}
\circ & 1 \text { - very low probability of occurrence, } \\
\circ & 2 \text { - low probability of occurrence, } \\
\circ & 3 \text { - average probability of occurrence, } \\
\circ & 4 \text { - high probability of occurrence, } \\
\circ & 5 \text { - very high probability of occurrence; }
\end{array}
$$

- $\mathrm{X}_{2}$ - impact on relations with customers (expressed in the form of assessments obtained through surveys), where:

○ 1 - very large negative impact,

- 2 - large negative impact,

○ 3-medium negative impact,

○ 4- little negative impact,

○ 5 - very little negative impact;

- $\mathrm{X}_{3}$ - significance of a given risk category - number of survey responses (expressed in $\%$ );

- $\mathrm{X}_{4}$ - costs associated with the occurrence of a given risk - in order to determine the most likely cost associated with the occurrence of a given risk $\left(C_{o}\right)$, a triple estimation was used (in accordance with the PERT methodology). Optimistic $\left(C_{c}\right)$, most likely $\left(C_{m}\right)$ and pessimistic $\left(C_{p}\right)$ cost values were adopted for each risk. The value was received via IDIs. The expected value of the beta distribution was calculated from the formula [14]:

$$
C_{o}=\frac{C_{c}+4 C_{m}+C_{p}}{6}
$$

Then, the calculation of key risks in carsharing activities were made. Firstly, the assignation of superior importance indicators and lesser importance indicators for the carsharing enterprises were made. The weights $\left(w_{i}\right)$ were determined by analysing in-depth interviews with representatives of carsharing companies. It should also be noted that each risk category has been described by 4 indicators, which are characterized by different units and the values 
associated with the highest level of risk in individual categories, once strive for maximum, once for minimum. This situation required aggregating all indicators into one synthetic indicator $\left(S_{i}\right)$, which allowed to obtain comparable results:

$$
S_{i}=\frac{1}{\sum_{i=1}^{n} w_{i}} \times \sum_{i=1}^{n}\left(w_{i} \times X_{i j}^{\prime}\right)
$$

where $\mathrm{X}_{\mathrm{ij}}$ represents aggregated values for individual indicators. Aggregated values were calculated from the formulas:

$$
\begin{gathered}
X_{i}^{\prime}=\frac{X_{i j}}{\max \left(X_{i j}\right)} \text { for values striving for maximum } \\
\text { or } \\
X^{\prime}{ }_{i}=\frac{\min \left(X_{i j}\right)}{X_{i j}} \text { for values striving for minimum }
\end{gathered}
$$

where $\mathrm{X}_{\mathrm{ij}}$ is the indicator value for a particular risk category. The maximum value means that the highest score is associated with the highest risk, the minimum - the lowest score is the highest risk.

It is also worth noting that:

$$
S_{i} \in(0 ; 1>
$$

In order to simplify the calculation, the weight values for individual indicators have been allocated using the percentage presented in decimal form:

$$
\sum_{i=1}^{n} w_{i}=1
$$

thus the formula for the synthetic indicator has been simplified to the form:

$$
S_{i}=\sum_{i=1}^{n}\left(w_{i} \times X_{i j}^{\prime}\right)
$$

The procedure carried out in this way leads to the aggregation of individual indicators into one synthetic indicator, which allows for prioritizing individual risk categories and placing them in the strategy of a carsharing company. 


\section{Results}

Through the observations and individual in-depth interviews (IDI), the following types of risk have been identified that occur in carsharing:

- $\mathrm{Y}_{1}-$ vehicle theft - for the purposes of the analysis, one of the most popular passenger carsharing vehicles in Poland (Renault Clio) was selected. For example, it is used by Traficar [10];

- $\mathrm{Y}_{2}$ - gasoline theft - the vehicle is not serviceable, it is necessary to refuel and possibly tow;

- $\quad Y_{3}$ - total damage of the vehicle - the car is not able for further use;

- $\mathrm{Y}_{4}$ - partial damage of the vehicle - the vehicle is able for further use after making the necessary repairs;

- $\mathrm{Y}_{5}$ - leaving the vehicle in a dangerous place - generates the risk of damage or theft - direct costs associated with the necessity of moving the vehicle or are connected with lost sales opportunities;

- $\mathrm{Y}_{6}$ - leaving the vehicle in an unauthorized place - risk of ticket receiving, towing away or damaging it;

- $\quad \mathrm{Y}_{7}$ - dirty exterior of the car - risk of losing customers and incurring washing costs;

- $\mathrm{Y}_{8}$ - dirty interior of the car - risk of losing customers and incurring cleaning costs;

- $\quad Y_{9}$ - running out of gasoline / discharging an electric vehicle during use - risk of losing customers, towing costs;

- $\mathrm{Y}_{10}$ - mobile application problems - risk of losing customers;

- $\mathrm{Y}_{11}$ - making the vehicle available to third parties - possibility of damage, problem with debt collection;

- $\mathrm{Y}_{12}$ - driving in the state of intoxication - the possibility of damage, the risk of losing customers, negative opinions from customers;

- $\mathrm{Y}_{13}$ - counterfeit documents during registration - a problem with establishing the driver's identity and with debt collection;

- $\mathrm{Y}_{14}$ - lack of funds for service fee - freezing capital, the need to start the debt collection.

Categories of risk listed above were assessed by respondents in terms of three measures and supplemented by the estimation of costs associated with their occurrence. The costs were estimated on the basis of the real value of vehicles, their equipment, fuel prices or costs related to transport related services - cleaning, towing, repairs or costs of debt collection process. Table 1 shows the results of the conducted research (rounded to two decimal places). 
Table 1

\section{Research results}

\begin{tabular}{|c|c|c|c|c|c|}
\hline & \multirow{2}{*}{$\begin{array}{l}\boldsymbol{m} \mathbf{X}_{\mathbf{1}} \\
\max \end{array}$} & \multirow{2}{*}{$\begin{array}{r}\boldsymbol{m} \mathbf{X}_{2} \\
\min \end{array}$} & \multirow{2}{*}{$\begin{array}{l}\mathbf{m} \mathbf{X}_{3} \\
{[\%]} \\
\max \end{array}$} & \multicolumn{2}{|l|}{$\begin{array}{l}\mathbf{X}_{4}[\mathbf{P L N}] \\
\max \end{array}$} \\
\hline & & & & $\mathrm{C}_{\mathrm{c}} ; \mathrm{C}_{\mathrm{m}} ; \mathrm{C}_{\mathrm{p}}$ & $\approx \mathrm{C}_{\mathrm{o}}$ \\
\hline $\mathbf{Y}_{1}$ & 2,58 & 1,93 & 37,88 & $\begin{array}{c}\mathrm{C}_{\mathrm{c}}=20000 ; \mathrm{C}_{\mathrm{m}}=50000 ; \mathrm{C}_{\mathrm{p}}=60000 \\
\text { the cost depends on the age and condition of the } \\
\text { car }\end{array}$ & 46667 \\
\hline $\mathbf{Y}_{2}$ & 2,69 & 2,31 & 12,12 & $\begin{array}{l}\qquad \mathrm{C}_{\mathrm{c}}=150 ; \mathrm{C}_{\mathrm{m}}=250 ; \mathrm{C}_{\mathrm{p}}=500 \\
\text { the cost depends on the price of gasoline and the } \\
\text { need for towing }\end{array}$ & 275 \\
\hline $\mathbf{Y}_{3}$ & 3,00 & 1,75 & 41,67 & $\begin{array}{c}\mathrm{C}_{\mathrm{c}}=20000 ; \mathrm{C}_{\mathrm{m}}=50000 ; \mathrm{C}_{\mathrm{p}}=60000 \\
\text { the cost depends on the age and condition of the } \\
\text { car }\end{array}$ & 46667 \\
\hline $\mathbf{Y}_{4}$ & 3,92 & 2,08 & 48,48 & $\begin{array}{l}\mathrm{C}_{\mathrm{c}}=2000 ; \mathrm{C}_{\mathrm{m}}=5000 ; \mathrm{C}_{\mathrm{p}}=20000 \\
\text { the cost depends on the scale of damage }\end{array}$ & 7000 \\
\hline$Y_{5}$ & 3,53 & 2,62 & 21,97 & $\begin{array}{l}\qquad \mathrm{C}_{\mathrm{c}}=20 ; \mathrm{C}_{\mathrm{m}}=50 ; \mathrm{C}_{\mathrm{p}}=200 \\
\text { the cost of moving the vehicle and customers loos- } \\
\text { ing }\end{array}$ & 70 \\
\hline$Y_{6}$ & 3,77 & 2,74 & 25,00 & $\begin{array}{l}\mathrm{C}_{\mathrm{c}}=20 ; \mathrm{C}_{\mathrm{m}}=100 ; \mathrm{C}_{\mathrm{p}}=1000 \\
\text { the cost of moving, towing away, parking and cus- } \\
\text { tomers loosing }\end{array}$ & 237 \\
\hline $\mathbf{Y}_{7}$ & 4,02 & 3,55 & 3,03 & $\begin{array}{l}\qquad \mathrm{C}_{\mathrm{c}}=10 ; \mathrm{C}_{\mathrm{m}}=30 ; \mathrm{C}_{\mathrm{p}}=80 \\
\text { the cost of traveling to the car wash and washing }\end{array}$ & 35 \\
\hline $\mathbf{Y}_{8}$ & 4,01 & 2,88 & 21,97 & $\begin{array}{l}\quad \mathrm{C}_{\mathrm{c}}=100 ; \mathrm{C}_{\mathrm{m}}=250 ; \mathrm{C}_{\mathrm{p}}=1000 \\
\text { the cost of traveling and cleaning service }\end{array}$ & 350 \\
\hline$Y_{9}$ & 3,40 & 2,39 & 11,36 & $\begin{array}{l}\qquad \mathrm{C}_{\mathrm{c}}=50 ; \mathrm{C}_{\mathrm{m}}=100 ; \mathrm{C}_{\mathrm{p}}=300 \\
\text { the cost of towing and customers loosing }\end{array}$ & 125 \\
\hline$Y_{10}$ & 3,19 & 2,44 & 23,48 & $\begin{array}{l}\mathrm{C}_{\mathrm{c}}=30 ; \mathrm{C}_{\mathrm{m}}=300 ; \mathrm{C}_{\mathrm{p}}=5000 \\
\text { the cost of customers loosing }\end{array}$ & 1038 \\
\hline$Y_{11}$ & 3,23 & 2,83 & 18,94 & $\begin{array}{c}\mathrm{C}_{\mathrm{c}}=0 ; \mathrm{C}_{\mathrm{m}}=30 ; \mathrm{C}_{\mathrm{p}}=150 \\
\text { the cost of non-payment, debt collecting and cus- } \\
\text { tomers loosing }\end{array}$ & 45 \\
\hline $\mathbf{Y}_{12}$ & 3,08 & 2,23 & 16,67 & $\begin{array}{l}\mathrm{C}_{\mathrm{c}}=0 ; \mathrm{C}_{\mathrm{m}}=30 ; \mathrm{C}_{\mathrm{p}}=1000 \\
\text { the cost of non-payment and a lawsuit }\end{array}$ & 187 \\
\hline $\mathbf{Y}_{13}$ & 2,65 & 2,48 & 15,15 & $\begin{array}{l}\mathrm{C}_{\mathrm{c}}=0 ; \mathrm{C}_{\mathrm{m}}=30 ; \mathrm{C}_{\mathrm{p}}=1000 \\
\text { the cost of non-payment and possible damage }\end{array}$ & 1687 \\
\hline$Y_{14}$ & 2,92 & 2,82 & 2,27 & $\begin{array}{l}\mathrm{C}_{\mathrm{c}}=0 ; \mathrm{C}_{\mathrm{m}}=30 ; \mathrm{C}_{\mathrm{p}}=100 \\
\text { the cost of non-payment }\end{array}$ & 37 \\
\hline
\end{tabular}


The values of the $X_{1}, X_{2}$ and $X_{3}$ measures presented in the table are the values obtained in the survey. Costs are indicative values, which should be considered individually in each case. Nevertheless, certain values must be adopted to conduct a risk analysis. Their size depends primarily on the scale of the problem or the occurring abuses. The values of individual measures were estimated using IDI. Triple cost estimation was used to best fit the model to reality.

The next part of the research was to calculate the value of the synthetic indicator. The following weights of individual factors were adopted in the study: $\mathrm{w}_{1}=0.30 ; \mathrm{w}_{2}=0.20$; $\mathrm{w}_{3}=0.20 ; \mathrm{w}_{4}=0.30$. The base for the establishing weights of individual factors were the expectations of carsharing companies. According to IDIs, the costs $\left(\mathrm{X}_{4}\right)$ and probability of risk occurrence $\left(\mathrm{X}_{1}\right)$ are the most important (they constitute $60 \%$ of weight). Customer relations (the $\mathrm{X}_{2}$ and $\mathrm{X}_{3}$ measures) represent $40 \%$ in the analysis (20\% per gauge). Table 2 presents the results of the conducted analysis (in order to obtain more accurate results, the values of the calculated indices have been rounded to four decimal places).

Table 2

Synthetic indicator results

\begin{tabular}{||c|c|c|c|c|c||}
\cline { 2 - 6 } \multicolumn{1}{c|}{} & $\begin{array}{c}\mathbf{X}_{\mathbf{1}} \\
\mathbf{w}_{\mathbf{1}}=\mathbf{0 , 3 0}\end{array}$ & $\begin{array}{c}\mathbf{X}_{\mathbf{2}} \\
\mathbf{w}_{\mathbf{2}}=\mathbf{0 , 2 0}\end{array}$ & $\begin{array}{c}\mathbf{X}_{\mathbf{3}} \\
\mathbf{w}_{\mathbf{3}}=\mathbf{0 , 2 0}\end{array}$ & $\begin{array}{c}\mathbf{X}_{\mathbf{4}} \\
\mathbf{w}_{\mathbf{4}}=\mathbf{0 , 3 0}\end{array}$ & $\Sigma$ \\
\hline $\mathbf{Y}_{\mathbf{1}}$ & 0,1925 & 0,1813 & 0,1563 & 0,3000 & $\mathbf{0 , 8 3 0 1}$ \\
\hline $\mathbf{Y}_{\mathbf{2}}$ & 0,2007 & 0,1515 & 0,0500 & 0,0018 & $\mathbf{0 , 4 0 4 0}$ \\
\hline $\mathbf{Y}_{\mathbf{3}}$ & 0,2239 & 0,2000 & 0,1719 & 0,3000 & $\mathbf{0 , 8 9 5 8}$ \\
\hline $\mathbf{Y}_{\mathbf{4}}$ & 0,2925 & 0,1683 & 0,2000 & 0,0450 & $\mathbf{0 , 7 0 5 8}$ \\
\hline $\mathbf{Y}_{\mathbf{5}}$ & 0,2634 & 0,1336 & 0,0906 & 0,0004 & $\mathbf{0 , 4 8 8 0}$ \\
\hline $\mathbf{Y}_{\mathbf{6}}$ & 0,2813 & 0,1277 & 0,1031 & 0,0015 & $\mathbf{0 , 5 1 3 6}$ \\
\hline $\mathbf{Y}_{\mathbf{7}}$ & 0,3000 & 0,0986 & 0,0125 & 0,0002 & $\mathbf{0 , 4 1 1 3}$ \\
\hline $\mathbf{Y}_{\mathbf{8}}$ & 0,2993 & 0,1215 & 0,0906 & 0,0022 & $\mathbf{0 , 5 1 3 6}$ \\
\hline $\mathbf{Y}_{\mathbf{9}}$ & 0,2537 & 0,1464 & 0,0469 & 0,0008 & $\mathbf{0 , 4 4 7 8}$ \\
\hline $\mathbf{Y}_{\mathbf{1 0}}$ & 0,2381 & 0,1434 & 0,0969 & 0,0067 & $\mathbf{0 , 4 8 5 1}$ \\
\hline $\mathbf{Y}_{\mathbf{1 1}}$ & 0,2410 & 0,1237 & 0,0781 & 0,0003 & $\mathbf{0 , 4 4 3 1}$ \\
\hline $\mathbf{Y}_{\mathbf{1 2}}$ & 0,2299 & 0,1570 & 0,0688 & 0,0012 & $\mathbf{0 , 4 5 6 9}$ \\
\hline $\mathbf{Y}_{\mathbf{1 3}}$ & 0,1978 & 0,1411 & 0,0625 & 0,0108 & $\mathbf{0 , 4 1 2 2}$ \\
\hline $\mathbf{Y}_{\mathbf{1 4}}$ & 0,2179 & 0,1241 & 0,0094 & 0,0002 & $\mathbf{0 , 3 5 1 6}$ \\
\hline
\end{tabular}

The conducted analysis allows for prioritizing individual risk categories in terms of their importance for car sharing companies. The analysis methodology presented in the article can also be a starting point for further in-depth research. Moreover, the results obtained may be the starting point for creating risk management strategies for car sharing companies. 


\section{Conclusion}

After the analysis, individual risk categories were ordered according to their importance for the risk management strategy of carsharing enterprises. Table 3 presents values of the synthetic measure in the hierarchical order.

Table 3

\section{Synthetic indicator results in descending order}

\begin{tabular}{||l|l|}
\hline$Y_{3}$ & $\mathbf{0 , 8 9 5 8}$ \\
\hline$Y_{1}$ & 0,8301 \\
\hline$Y_{4}$ & 0,7058 \\
\hline$Y_{6}$ & 0,5136 \\
\hline$Y_{8}$ & 0,5136 \\
\hline$Y_{5}$ & 0,4880 \\
\hline$Y_{10}$ & $\mathbf{0 , 4 8 5 1}$ \\
\hline
\end{tabular}

\begin{tabular}{|c|c|}
\hline$Y_{12}$ & 0,4569 \\
\hline$Y_{9}$ & 0,4478 \\
\hline$Y_{11}$ & 0,4431 \\
\hline$Y_{13}$ & 0,4122 \\
\hline$Y_{7}$ & 0,4113 \\
\hline$Y_{2}$ & 0,4040 \\
\hline$Y_{14}$ & 0,3516 \\
\hline
\end{tabular}

The key risks for car sharing companies will be total vehicle damage $\left(\mathrm{Y}_{3}\right)$, vehicle theft $\left(\mathrm{Y}_{1}\right)$ and partial vehicle damage $\left(\mathrm{Y}_{4}\right)$. This situation is associated with the higher costs of these events - in this case, a good solution is vehicle insurance and a record in the regulations about assignation of costs related to vehicle damage to the consumer - such solutions are used in practically in all carsharing companies, i. e. Traficar [11], Panek [9] or Drive Now [8]. The fee is also often transferred to the user in the situation when there is a necessity of paying a parking fee $\left(\mathrm{Y}_{6}\right)$, cleaning the car $\left(\mathrm{Y}_{8}\right)$ or when an unauthorized person drives a vehicle $\left(\mathrm{Y}_{11}\right)$.

Leaving the vehicle in a dangerous place $\left(\mathrm{Y}_{5}\right)$ may also be a big problem, as this may result in damage to the vehicle or loss of customers. The solution may be the so-called "cutting out zones", i.e. determining areas in which the car cannot be left.

Application problems $\left(\mathrm{Y}_{10}\right)$ are also a very important problem. Although they are not associated with high costs, they have a relatively large impact on the relationship with customers. What is more, according to the conducted research, problems with applications happen at times, which also has an impact on the company's image.

Driving in the state of intoxication $\left(\mathrm{Y}_{12}\right)$ is a very big problem for road safety. Furthermore, carsharing vehicles are often available in entertainment districts, which may encourage inebriated people to use them, e.g. when returning home. It should be noted, that driving in the state of intoxication is not a very important risk for carsharing companies - in the event of an accident, collision or dirt, they will hold the driver liable. Nevertheless, preventive actions may be part of the CSR strategy of carsharing operators.

Running out of gasoline or discharging an electric car $\left(\mathrm{Y}_{9}\right)$ during usage of vehicle is unlikely. This situation is caused by the care of enterprises to constantly supplement them. 
However it should be noted, that when such a situation occurs, it can contribute to significant traffic difficulties, negative opinion about the entrepreneur and, in the worst case, even to a collision or accident.

The use of counterfeit documents during registration $\left(\mathrm{Y}_{13}\right)$ is not a common situation. Although, it may lead to problems with determining the driver's data and the subsequent recovery of receivables, nevertheless, carsharing companies often protect themselves in additional way - the second stage of verification is the need to connect to the credit card system and / or make a small amount transfer. Such activities significantly impede the provision of false data. However, they do not protect the enterprise against possible losses related to the collection of receivables due to lack of funds for travel $\left(\mathrm{Y}_{14}\right)$. However, the losses in this case are small. What is more, usually after sending a reminder, the customer decides to pay. Nevertheless, in some cases it will be necessary to start the debt collection process, which is not profitable for small amounts (such as those usually associated with car journeys for minutes), which may result in the operator's unwillingness to initiate proceedings - the case will probably result in blocking the account. However these small, unrecovered amounts do not affect the overall balance of the enterprise (the effect of scale works here), they are also not often encountered, which is why this risk was ranked last in the hierarchy.

Dirty exterior of the car $\left(\mathrm{Y}_{7}\right)$ is the situation with the highest probability of occurrence. On the other hand, the costs associated with levelling it are small, and the mere contamination of the car body does not affect the customer's decision to rent a vehicle. The standard public approach is the fact that cars are utility items, which can be dirty. Moreover, soiling the car outside does not affect the comfort of traveling (unless the windows, lights or mirrors are dirty).

Gasoline theft $\left(\mathrm{Y}_{2}\right)$ in modern times is quite a common situation (especially in transport companies). This situation is primarily related to gasoline prices - a strong correlation can be observed between the number of thefts and the price of gasoline [13]. Nevertheless, there are many effective methods to prevent theft. What is more, vehicles of the carsharing fleet are constantly monitored, so thieves prefer to steal from a private cars.

\section{Discussion}

The analysis allowed to obtain a catalogue of risks related to carsharing activities and to prioritize them in terms of importance for operators. To the best of the author's knowledge, no article dealing with these issues has been published until then. The author is also aware of the diversity of expectations of individual operators, which means that the conducted research indicates only the most important factors in the industry. Moreover, the choice of measures for assessing individual risk categories will also depend on the individual preferences of operators. Nevertheless, the analysis may prove to be the foundation for further research and provide a starting point for creating risk assessment strategies in carsharing activities. 
It also should be noted that each analysis is tailored to a specific market. The approach of customers, the likelihood of a given risk or prices may vary depending on the geographical location, the economic system of a given country or cultural conditions. This analysis is adapted to the specifics of the Polish market, however, some features may be common with other areas.

The author's goal was to identify a research gap regarding the concept of sharing economics and to initiate an academic debate on this topic. This article is to constitute an introduction to further, extended research in this field.

\section{References}

1. Amabile T. M.: Creativity and Innovation in Organizations. Harvard Business School Background Note, No. 396-239, 1996.

2. Bardhi F., Eckhardt G. M.: Access-Based Consumption: The Case of Car Sharing. Journal of Consumer Research, Vol. 39, Iss. 4, 2012.

3. Boyce C., Neale, P.: Conducting In-depth Interviews: A Guide for Designing and Conducting In-Depth Interviews for Evaluation Input, Pathfinder International Tool Series. Monitoring and Evaluation, No. 2, 2006.

4. Cisek S.: Metoda analizy i krytyki piśmiennictwa w nauce o informacji i bibliotekoznawstwie w XXI wieku. Przegląd Biblioteczny, no. 3, 2010.

5. Felson M., Spaeth J.: Community Structure and Collaborative Consumption: A Routine Activity Approach. The American Behavioral Scientist, No. 21 (4), 1978.

6. Flügge B.: Smart Mobility - Connecting Everyone. Trends, Concepts and Best Practices, Springer Vieweg, Wiesbaden 2017.

7. Hanusik A.: Y-generation's Perception of Sharing Economy, 12th International Scientific Conference "Analysis of International Relations 2019. Methods and Models of Regional Development”. Conference Proceedings, Publishing House of the University of Economics in Katowice, Katowice 2019.

8. https://www.drive-now.com/gb/en/pricing/standard-fees.

9. https://www.ipanek.pl/sites/all/pliki/regulamin_rac_6.03.2019.pdf.

10. https://www.traficar.pl/cars.

11. https://www.traficar.pl/regulamin/pl/regulamin.html/.

12. Lovelock Ch., Gummesson E.: Whither Service Marketing? In Search of a New Paradigm and Fresh Perspectives. Journal of Service Research, No. 7 (1), 2004.

13. Moffatt S., Fitzgerald, J.: The relationship between petrol theft and petrol prices. Crime and Justice Bulletin: Contemporary Issues in Crime and Justice, No. 101, 2006.

14. Patan M.: Badania operacyjne. Programowanie sieciowe. Metoda PERT. Instytut Sterowania i Systemów Informatycznych. Uniwersytet Zielonogórski.

15. Paulus P., Dzindolet B. M.: Social Influence, Creativity and Innovation, Social Influence, No. 3 (4), 2008. 
16. Rudawska I.: Ekonomia dzielenia się, czyli konsumpcja współdzielona i inne formy alternatywnego dostępu do dóbr, Studia Ekonomiczne. Zeszyty Naukowe Uniwersytetu Ekonomicznego w Katowicach, No. 254, 2016. 